\title{
SUPERVISI PROFESIONALITAS GURU DI MASA PANDEMI CORONA
}

\author{
Faniyatul Mazaya \\ Universitas Islam Negeri Maulana Malik Ibrahim Malang \\ e-mail: efmazaya@gmail.com
}

\begin{abstract}
Educational supervision can be interpreted as a science that studies how to supervise human resources involved in the world of education (teachers) to work in accordance with the objectives of the school, educational supervision is carried out by educational supervisors. Corona pandemic requires teachers to be able to conduct learning even though they are not face to face. This is felt to be difficult because of the many limitations possessed by both teachers, students, and concerning the lack of existing infrastructure. One effort to control the course of distance learning is to supervise teacher professionalism. The research method used is qualitative with the type of literature study. The results of the study show that first, education supervision is absolutely necessary to find out the quality of learning and all forms of administration. Secondly, supervision of the professionalism of teachers in the pademi corona period is also important and even mandatory. It aims to determine the performance of teachers in conducting a series of distance learning. As a teacher it is necessary to carry out their duties and obligations under any conditions, including conditions that require distance learning. Third, supervision of the professionalism of teachers during the corona pandemic can be done through several stages : the planning stage, the implementation phase, the evaluation stage, the evaluation stage, and the improvement phase.
\end{abstract}

Keywords. Supervisioan, teacher professionalism, corona pandemic

Abstrak. Supervisi pendidikan bisa diartikan sebagai kegiatan yang mempelajari bagaimana mengawasi Sumber Daya Manusia (SDM) dalam dunia pendidikan (guru) agar bekerja sesuai dengan tujuan sekolah, supervisi pendidikan dilakukan oleh supervisor pendidikan. Pandemi corona menuntut guru untuk bisa mengadakan pembelajaran meski non tatap muka. Hal tersebut dirasa sulit karena banyak keterbatasan yang dimiliki baik oleh guru, peserta didik, maupun menyangkut minimnya sarana prasarana yang ada. Salah satu upaya untuk mengontrol berjalannya pembelajaran jarak jauh adalah dengan melakukan supervisi profesionalitas guru. Metode penelitian yang dipakai ialah kualitatif dengan pendekatan studi kepustakaan. Hasil penelitian menunjukkan pertama, supervisi pendidikan mutlak diperlukan untuk mengetahui kualitas pembelajaran beserta segala bentuk administrasinya. Kedua, supervisi profesionalitas guru di masa pademi corona juga penting dan bahkan wajib dilakukan. Hal itu bertujuan agar dapat mengetahui kinerja guru saat melakukan serangkaian pembelajaran jarak jauh. Sebagai seorang guru sudah seharusnya untuk menjalankan tugas dan kewajibannya dalam kondisi apapun, termasuk kondisi yang mengharuskan melakukan pembelajaran jarak jauh. Ketiga, supervisi profesionalitas guru di masa pandemi corona ini dapat dilakukan dengan melalui beberapa tahap yakni tahap : perencanaan, pelaksanaan, penilaian, evaluasi, dan perbaikan.

Kata Kunci. Supervisi, profesionalitas guru, pandemi corona.

Copyright (C) JMPI: Jurnal Manajemen Pendidikan Islam. All Right Reserved.

This is an open access article under the CC BY-NC-ND license

(http://creativecommons.org/licenses/by-nc-nd/4.0/). 


\section{A. PENDAHULUAN}

Pendidikan mempunyai peranan yang sangat penting dalam rangka mempersiapkan generasi muda yang mempunyai kecerdasan intelektual, kecakapan emosional, dan kondisi spiritual yang mumpuni. Di era abad 21 ini, peserta didik dituntut untuk dapat belajar mandiri kapanpun dan dimanapun. (Sulisworo, 2013). Melalui pendidikan juga akan terbentuk baik atau buruknya pribadi manusia yang nantinya akan menentukan kualitas suatu bangsa. Maka dari itu, sudah semestinya pendidikan mendapatkan perhatian serius. Keberhasilan mengelola pendidikan dipengaruhi oleh banyak hal seperti kompetensi kepala sekolah, supervisi akademik, profesionalitas guru, sarana prasarana, dan iklim kerja. Dari beberapa faktor diatas, profesionalitas guru menjadi salah satu faktor inti keberhasilan pendidikan.

Dalam dunia pendidikan, hal yang juga sangat penting diperhatikan ialah mengenai supervisi. Supervisi atau pengawasan dalam dunia pendidikan dilakukan oleh seorang pengawas pendidik. Pengawas pendidikan terbagi menjadi dua, yakni pengawas pendidikan dari departemen pendidikan dan juga seorang kepala sekolah yang merupakan pemimpin tertinggi di sebuah sekolah. Pelaksanaan pendidikan di sebuah sekolah merupakan tanggungjawab kepala sekolah sebagai seorang manajer, leader, inovator, edukator, supervisor, dan juga motivator. Maka profesionalisme guru juga merupakan hal yang patut diawasi oleh seorang kepala sekolah.

Profesionalitas guru mempunyai peran yang sangat penting pada kegiatan belajar baik didalam kelas/luar kelas. Dalam sebuah proses pendidikan, guru mempunyai tugas ganda, yakni sebagai seorang pengajar dan juga seorang pendidik (Djamarah dan Anwar Zain, 2002). Sebagai seorang pengajar guru bertugas sebagai mediator dan fasilitator untuk memberi materi pembelajaran kepada peserta didik. Sedangkan sebagai seorang pendidik, guru mempunyai tugas untuk senantiasa mengarahkan dan juga membina peserta didik agar senantiasa menjadi pribadi dengan perilaku baik, sopan, kreatif, bertanggungjawab, dan mandiri.

Guru memiliki peran inti pada proses pembelajaran, oleh sebab itu maka kualitas dan profesionalitas guru harus mendapat perhatian. Mutu pendidikan di suatu sekolah tergantung pada kualitas dan profesionalitas gurunya, untuk itu perlu diadakan supervisi profesionalitas guru untuk memastikan bahwa guru mempunyai kompetensi yang harus sesuai dengan Standar Nasional Pendidikan. Profesi guru ialah profesi yang membutuhkan keahlian sehingga diperlukan pendidikan yang sesuai dan pengalaman yang mumpuni untuk menjadi seorang guru yang profesional.

Sebagai salah satu dari beberapa unsur pendidikan, guru dituntut berperan aktif dan dapat memposisikan dirinya sebagai seorang tenaga pendidik yang profesional berdasarkan kondisi dan tuntutan dari masyarakat. Guru diharapkan dapat menjadi pengajar handal yang mampu mentransfer ilmu pengetahuan dan juga pembimbing yang dapat mentransfer nilai-nilai positif di kehidupan sehari-hari peserta didik. Guru yang profesional diharapkan bisa menghasilkan lulusan berkompeten dan dapat bersaing baik ditingkat regional, nasional, dan juga internasional. Profesionalitas guru sebagai salah satu komponen dalam penerapan kurikulum harus mendapat perhatian. Kegiatab pembelajaran memerlukan keterampilan yang akan mewujudkan kelancaran kegiatan pembelajaran secara baik, efektif, dan juga efesien (Saefudin, 2009).

Pandemi corona yang sedang melanda Indonesia saat ini sangat berdampak 
pada kondisi pendidikan. Hal tersebut karena semua sekolah, madrasah, dan juga perguruan tinggi diliburkan sehingga peserta didik harus menjalani belajar mandiri dirumah masing-masing atau biasa disebut pembelajaran jarak jauh (PJJ). Namun faktanya terdapat beberapa kendala yang harus dihadapi. Salah satu dari sekian kendala tersebut adalah rendahnya kemampuan dan kreatifitas tenaga pendidik untuk tetap melakukan kegiatan belajar mengajar non tatap muka. Hal itu terjadi karena minimnya profesionalisme guru dan juga keterbatasan sarana prasarana yang dimiliki baik guru maupun peserta didik.

Pandemi corona menuntut guru untuk bisa mengadakan pembelajaran meski non tatap muka. Hal tersebut dirasa sulit karena banyak keterbatasan yang dimiliki baik oleh guru, peserta didik, maupun menyangkut minimnya sarana prasarana yang ada. Salah satu upaya untuk mengontrol berjalannya pembelajaran jarak jauh adalah dengan melakukan supervisi profesionalitas guru.

Supervisi pendidikan dapat diartikan sebagai suatu ilmu pengetahuan yang bertujuan untuk dapat menerapakan metode bagaimana mengawasi Sumber Daya Manusia (SDM) yang berkecimpung pada dunia pendidikan (guru) agar bekerja sesuai dengan tujuan sekolah, supervisi pendidikan dilakukan oleh supervisor pendidikan (kepala sekolah atau pengawas pendidikan). Pengawasan disini juga mencakup perencanaan, pengamatan, perbaikan, dan pembinaan. Dalam proses supervisi profesionalitas guru diperlukan adanya pengawasan terhadapa kinerja guru. Pengawasan atau supervisi itu bisa berupa kunjungan kelas, wawancara individu, observasi kelas, saling mengunjungi sesama guru, metode angket, evaluasi diri, dan lainnya (Muhammad Fatih, 2018).

Berdasarkan pemaparan diatas, maka perlu adanya kajian mengenai supervisi profesionalitas guru di masa pandemi corona agar pembelajaran tetap bisa dilakukan dengan baik. Penelitian ini bertujuan untuk memaparkan hasil penelitian mengenai supervisi profesionalitas guru yang dilakukan dengan metode penelitian studi kepustakaan di masa terjadinya pandemi corona di Indonesia.

\section{B. METODE}

Penelitian mengenai supervisi profesionalitas guru ini menggunakan pendekatan kualitatif dengan kategori penelitian studi kepustakaan. Studi kepustakaan (Library Research) ialah metode yang dipakai untuk dapat mengumpulkan informasi juga data melalui buku atau media perpustakaan seperti dokumen, buku, dan majalah. Koentjaraningrat mengungkapkan bahwa teknik kepustakaan adalah cara untuk mengumpulkan data yang ada diruang kepustakaan, seperti buku rujukan, ensiklopedia, majalah, naskah, dokumen, dan sebagainya yang sesuai dengan kebutuhan (Koentjaraningrat. 1984:420). Sedangkan menurut Sugiyono, metode studi kepustakaan adalah hal yang penting dalam melakukan sebuah penelitian. Hal tersebut karena penelitian apapun tidak dapat terlepas dari literatur ilmiah (Sugiyono, 2012:291). Studi kepustakaan menurut Zed ialah serangkaian kegiatan yang berhubungan dengan cara pengumpulan data-data pustaka, mengumpulkan referensi, menulis hasil temuan, dan memproses data penelitian yang dibutuhkan (Mestika Zed, 2003:3).

Dalam sebuah penelitian jenis studi kepustakaan, beberapa hal utama yang harus diperhatikan, yakni: (1) bahwa peneliti ini berhubungan dengan tulisan dan atau 
data berbentuk angka dan bukan data-data di lapangan, (2) data ini bersifat siap pakai karena peneliti tidak hadir langsung ke lapangan, (3) data pustaka umumnya bersifat sekunder, artinya bahwa si peneliti mendapat data dari pihak kedua karena bukan data langsung dari lokasi penelitian, (4) data pustaka tidak terbatas oleh ruang dan juga waktu. Hal tersebut dipaparkan oleh Supriyadi dalam jurnalnya (Supriyadi, 2016).

\section{HASIL DAN PEMBAHASAN}

\section{Pengertian Supervisi}

Supervisi dalam penelitian ini dimaknai sebagai sebuah kegiatan supervisi atau pengawasan yang diterapkan dibidang pendidikan. Menurut Suharsimi Arikunto, supervisi berasal dari 2 suku kata yakni "super" yang artinya atas serta "vision" yang berarti "melihat". Secara umum, supervisi dapat diartikan sebuah kegiatan melihat atau mengawasi pekerjaan secara keseluruhan dengan sangat teliti (Arikunto, 2004). Super bisa diartikan atas / lebih, sedangkan kata vision artinya meninjau. Jadi secara etimologi, kata supervisi (supervision) dapat diartikan melihat / meninjau sesuatu dari atas yang dilakukan oleh seorang atasan sebagai bentuk pengawasan kinerja bawahannya (Nawawi, 1996).

Konsep awal dari kegiatan supervisi pendidikan ialah adanya kebutuhan para guru agar dapat memperoleh pertolongan atau masukan untuk menyelesaikan kesulitan saat kegiatan belajar mengajar (Sagala, 2010). Bantuan yang diharapakan adalah bantuan untuk membimbing guru dalam memilih metode mangajar, menggunakan media belajar, mengkondisikan peserta didik, melakukan penilaian, sampai mengadakan remidi atau pengayaan.

Hakikat dari suervisi pendidikan adalah proses bimbingan oleh pihak atasan (pengawas sekolah atau kepala sekolah) kepada para tenaga pendidik atau kependidikan. Supervisi dilakukan untuk meningkatkan dan memperbaiki kegiatan pembelajaran agar para peserta didik bisa belajar secara maksimal dan mendapatkan layanan pendidikan yang maksimal agar mendapat hasil belajar sesuai harapan. Orang yang biasa melakukan kegiatan supervisi / pengawasan memiliki jabatan sebagai supervisor / pengawas (Sukatin, 2016).

Dalam perkembangannya supervisi diartikan sebagai pelayanan untuk guru dengan tujuan memperbaiki proses pembelajaran dan juga penerapan kurikulum sesuai jenjang dan jenis pendidikan. Supervisi, sebagai bentuk pelayanan kepada para guru bertujuan menghasilkan peningkatan dan perbaikan dalam kegiatan belajar mengajar. Selanjutnya, supervisi juga direncanakan sebagai kegiatan pembinaan yang untuk dapat membantu para tenaga pendidikan dan kependidikan di sebuah sekolah dalam melakukan tugas mereka secara maksimal, efektif, dan efisien (Purwanto, 2007).

Supervisi pendidikan ialah suatu usaha untuk memberi stimulus, mengkordinir, serta membimbing secara berkelanjutan kinerja guru maupun tenaga kependidikan di sebuah sekolah, baik secara perorangan ataupun secara kelompok, agar bisa maksimal dan efektif saat menjalankan tugas dan kewajiban dengan harapan mereka dapat mengajar dan memberi layanan pendidikan sebaik mungkin (Maralih, 2014).

Ada beberapa hal yang penting untuk diperhatikan mengenai supervisi dalam bidang pendidikan, yakni: (1) adanya proses pengarahan / bimbingan dari atasan selaku pihak yang lebih mengerti dan profesional. (2) guru juga tenaga kependidikan sekolah lainnya yang selalu berinteraksi secara langsung dengan peserta didik saat 
kegiatan pembelajaran (3) proses atau kegiatan belajar mengajar atau situasi pebelajaran yang menjadi objek supervisi (Pidarta, 1992).

Tujuan utama supervisi pendidikan ialah untuk memberi bantuan dan pelayanan kepada tenaga pendidik dan kependidikan agar dapat mengembangkan kualitas pembelajaran, memfasilitasi guru untuk bisa mengadakan kegiatan pembalajaran yang efektif, serta bekerjasama dengan semua komponen sekolah termasuk orang tua untuk meningkatkan kualitas pendidikan dan lulusan. Selain itu supervisi bertujuan untuk mengembangkan kurikulum dan meningkatkan profesionalitas sumber daya manusia di sebuah sekolah (Suhardan, 2010).

Supervisi pendidikan dilakukan dengan menerapkan prinsip-prinsip yang sudah ditentukan, yakni:

a. Ilmiah (scientific)

Dalam pelaksanaan kegiatan supervisi hendaknya dilakukan dengan ilmiah, maksudnya adalah pelaksanaan supervisi harus sistematis, teratur, terstruktur, berkesinambungan, objektif, berdasar pada data dan ilmu pengetahuan, serta memakai instrumen yang bisa memberi data akurat dan dapat dianalisa dan juga dapat mengukur keberhasilan pelaksanaan proses belajar mengajar.

b. Demokrasi

Dalam implementasi sebuah supervisi, harus senantiasa menjunjung konsep musyawarah, mempunyai rasa kekeluargaan, saling menghargai, serta dapat menerima usul / masukan dari orang lain.

c. Kooperatif

Dalam melaksanakan supervisi hendaknya dapat saling bekerjasama agar dapat menciptakan kondisi pembelajaran yang baik.

d. Konstruktif dan juga kreatif

Pelaksanaan kegiatan supervisi hendaknya bisa menumbuhkembangkan ideide guru serta memberi motivasi agar dapat selalu aktif dalam menciptakan kondisi pembelajaran efektif (Rifa''i, 1987).

Teknik melakukan supervisi bidang pendidikan adalah cara yang dilakukan untuk dapat memberi pelayanan serta pembinaan kepada guru agar bisa melaksanakan tugas serta tanggungjawabnya sebagai upaya dalam mencapai tujuan pendidikan yang sudah disepakati dengan maksimal, efektif, dan efisien (Asnawir, 2007). Ada 3 teknik yang dapat digunakan dalam pelaksanaan supervisi, yakni:

a. Teknik supervisi langsung dan teknik tidak langsung

Teknik supervisi secara langsung dilakukan melalui cara mengobservasi langsung saat guru melakukan kegiatan pembelajaran di kelas. Ada tiga tahapan dalam teknik supervisi langsung ini, yakni pra observasi (dilakukan dengan diskusi bersama guru sebelum melakukan observasi), tahapan observasi (melakukan kunjungan kelas), dan tahapan post observasi (setelah observasi selesei kemudian supervisor dan guru mendiskusikan kekurangan dan kelebihan kegiatan pembelajaran). Sedangkan supervisi tidak langsung bisa diterapkan dengan beberapa metode / cara, antara lain yakni dengan melakukan tes atau kunjungan mendadak, atau metode angket (Lantip Diat dan Sudiyono, 2011). 
b. Teknik supervisi individu dan teknik kelompok

Teknik supervisi individu bisa dilakukan dengan kunjungan kelas, kunjungan antar guru, atau evaluasi perseorangan. Sedangkan teknik kelompok dapat dilakukan dengan rapat staf sekolah, orientasi guru baru, atau melalui demonstrasi mengajar.

c. Teknik supervisi lisan dan tulisan

Teknik supervisi lisan bisa dilakukan denga metode wawancara, diskusi atau rapat bersama. Sedangkan teknik supervisi tulisan bisa dilakukan dengan pengisian angket atau kuisioner.

\section{Supervisi Profesionalitas Guru}

Secara bahasa, profesionalitas berasal dari bahasa Inggris yakni "profession" yang berarti mampu atau ahli dalam satu pekerjaan (Ahmad Sanusi, 1991). Jadi dapat diartikan bahwa orang yang mendapat julukan profesional adalah seorang yang ahli dan mumpuni dalam melakukan profesi atau pekerjaan tertentu. Untuk bisa menjadi seorang yang profesional diperlukan pendidikan atau latihan khusus.

Guru profesional ialah guru yang mampu menjalankan tugas dan juga kewajibannya menjadi seorang pengajar sekaligus pendidik dengan baik. Berdasarkan UU 14 Thn 2005, kewajiban guru serta juga dosen adalah:

a. Dapat membuat perencanaan program pembelajaran, melakukan proses pembelajaran berkualitas, dan menilai serta mengevaluasi seluruh hasil pembelajaran peserta didik

b. Mampu untuk mengembangkan dan juga meningkatkan kualifikasi akademik serta kompetensi yang dimiliki berdasarkan perkembangan ilmu dan juga teknologi

c. Mampu bersifat objektif dan tidak mencoba untuk diskriminatif dalam kegiatan pembelajaran

d. Mampu menjunjung peraturan, hukum, UU, nilai-nilai agama, etika, dan kde etik guru dengan baik

e. Sanggup menjaga persatuan serta kesatuan bangsa

Sebagai sebuah profesi, guru wajib memiliki kualifikasi pendidikan yang sesuai berdasarkan peraturan pemerintah. Guru juga harus memenuhi standar, yakni kesesuaian mata pelajaran yang diampu dengan bidang keilmuan yang ditekuninya. Guru sebagai seorang ujung tombak pelaksanaan pembelajaran wajib untuk senantiasa diperhatikan dan didukung untuk terus mengembangkan kemampuannya. Salah satu usaha peningkatan profesionalitas guru ialah melalui superisi profesionalitas. Pelaksanaan supervisi harus dilakukan dengan baik dan terencana agar memberi efek postif bagi perkembangan kinerja guru. Bentuk profesionalitas seorang guru adalah baik buruknya perilaku guru saat proses belajar mengajar berlangsung, yakni bagaimana guru membuat perencanaan pembelajaran, melakukan kegiatan pembelajaran, dan juga memberi penilaian hasil belajar para peserta didik.

Untuk dapat menjadi guru profesional diperlukan beberapa kompetensi seperti yang tertera di UU Guru dan Dosen. Kompetensi tersebut meliputi:

a. Kompetensi Pedagogik

Pada kompetensi ini para guru wajib dapat mengatur kegiatan belajar mengajar yang mencakup tingkat pemahaman para peserta didik, rencana 
pembelajaran serta pelaksanaan kegiatan pembelajaran, melakukan evaluasi hasil belajar, dan juga peningkatan potensi peserta didik.

b. Kompetensi Kepribadian

Dalam kompetensi ini seorang guru harus mempunyai kepribadian baik, dewasa, berwibawa, berakhlak mulia, mudah bergaul, dan bisa menjadi contoh untuk peserta didik.

c. Kompetensi Profesional

Maksud dari kompetensi profesional ialah kemampuan seorang guru untuk bisa mengerti materi pelajaran sebaik mungkin sehingga dapat mengarahkan peserta didik untuk bisa memenuhi standar kompetensi sesuai SNP.

d. Kompetensi Sosial

Maksud dari kompetensi sosial ialah kemampuan para guru untuk bisa menjalin komunikasi dan sosialisasi dengan para peserta didik, kepada sesama tenaga pendidik dan kependidikan, wali murid, dan masyarakat di sekitar.

Selain komptensi yang telah dijelaskan di UU, guru profesional juga harus mempunyai keterampilan untuk melaksanakan pembelajaran. Keterampilan tersebut yakni:

a. Keterampilan memulai dan menutup kegiatan pelajaran

Guru harus bisa membuka atau memulai pelajaran dengan cara yang menyenangkan untuk memberi kesan yang baik kepada peserta didik pada awal kegiatan belajar mengajar, sehingga peserta didik bisa antusias dan bersemangat. Seorang guru juga harus bisa menutup atau mengakhiri kegiatan belajar dengan baik agar peserta didik tidak trauma untuk mengikuti pembelajaran di lain waktu.

b. Keterampilan menjelaskan

Saat menjelaskan materi pelajaran, guru harus bisa menjelaskan dengan cara yang menyenangkan agar peserta didik mudah untuk mengerti materi pelajaran dan tidak bosan sehingga diharapkan tujuan dari pembelajaran dapat tercapai dan kegiatan pembelajaran bisa berjalan maksimal, efektif, dan efisien.

c. Keterampilan bertanya

Seorang guru harus mempunyai kemampuan bertanya yang baik agar para peserta didik dengan mudah mengerti pertanyaan dan bisa memberikan jawaban yang maksimal. Dengan demikian guru mampu mengetahui batasan tingkat pemahaman para siswa terhadap materi pelajaran.

d. Keterampilan memberi penguatan

Setelah menjelaskan materi pelajaran, guru juga harus dapat memberi penguatan materi agar peserta didik tidak cepat lupa terhadap materi dan mudah mengingat hal apa saja yang sudah dipelajari.

e. Keterampilan menggunakan media belajar

Seorang guru juga dituntut untuk dapat menggunakan berbagai media belajar agar kegiatan belajar tidak monoton, bisa berlangsung maksimal, dan peserta didik tidak cepat bosan.

f. Keterampilan membimbing diskusi

Seorang guru juga dituntut untuk bisa membimbing berjalannya proses 
diskusi eserta didik. Hal ini bertujuan agar peserta didik berani mengemukakan pendapatnya, bisa saling menghargai pendapat orang lain, dan bisa memperdalam pemahaman mereka melalui diskusi.

g. Keterampilan mengelola kelas

Guru adalah ujung tombak kegiatan pembelajaran, sudah seharusnya guru mampu mengelola kelas agar kegiatan pembelajaran berjalan maksimal dan peserta didik bisa mecapai hasil belajar maksimal.

h. Keterampilan mengadakan variasi dalam pembelajaran

Pembelajaran bisa menjadi kegiatan yang membosankan dan menjenuhkan bagi peserta didik, untuk itulah seorang guru juga harus bisa mengadakan variasi saat pembelajaran agar peserta didik tetap antusias sehingga pembelajaran dapat berjalan sebagaimana mestinya.

Guru sebagai seorang pengajar dan pendidik merupakan faktor yang berperan dalam kesuksesan atau kegagalan upaya pendidikan. Dengan demikian adanya inovasi pendidikan atau pengembangan kurikulum akan bermuara ke guru sebagai pemeran utama dalam kegiatan belajar mengajar.hal tersebut menunjukkan betapa vilatnya peran seorang guru (Mukhtar dan Iskandar, 2009).

Secara profesional, guru adalah tokoh sentral yang berpengaruh pada usaha membentuk sumber daya manusia (SDM) yang bermutu. Sorang guru juga mempunyai banyak peran dalam dunia pendidikan. peran tersebut dapat berupa pengajar, pendidik, pembimbing, pengatur lingkungan, pemimpin kelas, ekspeditor, supervisor, perencana, konselor, motivator, dan lain sebagainya (Mukhtar dan Iskandar, 2009).

Untuk mengetahui sejauh mana kompetensi dan keterampilan yang dimilili oleh seorang guru, maka perlu diadakannya supervisi profesionalitas guru dalam menjalankan tugas dan kewajibannya. Ada beberapa tahapan dalam supervisi profesionalitas guru, yakni:

a. Perencanaan supervisi

Tahap pertama supervisi adalah membuat perencanaan. Dalam tahapan ini dirinci terlebih dahulu jenis supervisi apa yang akan dilakukan, waktu pelaksanaan, metode yang digunakan, penilaian guru berdasarkan hasil supervisi, dan evaluasi kegiatan supervisi.

b. Pelaksanaan supervisi

Tahap kedua adalah tahap pelaksanaan. Dalam tahap ini seorang supervisor atau pengawas mulai melakukan supervisi sesuai dengan perencanaan yang sudah dibuat sebelumnya. Pelaksanaan harus dilakukan sebaik mungkin sesuai dengan perencanaannya.

c. Penilaian hasil supervisi

Setelah melakukan supervisi, maka seorang supervisor harus melakukan penilaian terhadap hasil supervisi yang sudah dilakukan. Penilaian ini bisa dalam bentuk angka atau narasi.

d. Evaluasi hasil supervisi

Tahap selanjutnya adalah melakukan evaluasi terhadap hasil supervisi, apakah kinerja subjek supervisi sudah baik dan apakah supervisi sudah berjalan sesuai perencanaan.

e. Perbaikan

Tahapan supervisi yang terakhir adalah melakukan perbaikan. Perbaikan 
yang dimaksud disini mencakup dua hal, pertama perbaikan kualitas kompetensi dan keterampilan guru dalam kegiatan belajar mengajar. Kedua adalah perbaikan teknik dan sistematika supervisi agar supervisi selanjutnya dapat lebih efektif dan efisien (Haidar Nawawi, 1988).

\section{Supervisi Profesionalitas Guru di Masa Pandemi Corona}

Berdasarkan pemaparan mengenai tugas, kewajiban, kompetensi, dan keterampilan yang harus dimiliki guru, maka perlu diadakannya supervisi profesionalitas guru. Supervisi ini bertujuan untuk mengetahui sejauh mana seorang guru dapat melaksanakan tugas dan kewajibannya meski tidak melakukan pembelajaran secara tatap muka karena adanya pandemi corona. Sebagaiman yang diketahui bersama, pandemi corona menyebabkan pemerintah meliburkan sekolah, madrasah, dan perguruan tinggi untuk mengantisipasi persebaran virus corona. Sebagai gantinya, menteri pendidikan menerapkan konsep untuk belajar di rumah bagi semua peserta didik. Meski peserta didik belajar dari rumah, hal itu tidak lepas dari peran seorang guru sebagai aktor utama dalam kegiatan pembelajaran.

Pendidikan yang efektif membutuhkan kolaborasi dari guru, peserta didik, dan orang tua. Kolaborasi tersebut sangat dibutuhkan terutama di masa pandemi corona dimana peserta didik melakukan pembelajaran. Pandemi virus corona menjadi tantangan bagi kehidupan bermasyarakat dan bernegara. Selain itu virus corona juga menjadi tantangan tersendiri bagi dunia pendidikan. Untuk pertama kalinya dalam sejarah guru harus melakukan pembelajaran secara daring dengan memanfaatkan teknologi dan fasilitas yang sangat canggih. Oleh karena itu, guru dan juga orang tuawajib menyadari bahwa pembelajaran harus tetap terjadi dimana pun. Selain itu orang tua juga menyadari betapa sulitnya tugas dan kewajiban guru.

Dimasa pandemi corona ini guru harus memastikan kegiatan pembelajaran tetap berjalan meski peserta didik berada dirumah masing-masing. Solusi yang bisa dilakukan guru adalah dengan mendesain kegiatan pembelajaran sesuai dengan media pembelajaran daring (online). Hal itu sesuai dengan kebijakan menteri pendidikan dan kebudayaan RI dalam surat edaran nomer 4 thn 2020 mengenai pelaksanaan kebijakan program pendidikan di masa darurat penyebaran virus corona / covid 19.

Sistem pembelajaran yang bisa dilakukan saat ini adalah melalui perangkat personal computer (pc) atau laptop yang harus terhubung dengan internet. Selain itu guru dapat melakukan pembelajaran atau mengontrol kegiatan belajar dan tugas peserta didik melalui grup whatsappp (wa) atau telegram, aplikasi zoom, atau media lainnya. Dengan demikian, guru bisa memastikan bahwa peserta didik tetap melakukan pembelajaran meski berada di rumah. Ada beberapa tahapan yang dapat dilakukan dalam supervisi profesionalitas guru di masa pandemi corona sebagaimana yang sudah penulis kutip dari tulisan Haidar Nawawi (1988), yakni:

a. Perencanaan supervisi

Dalam tahapan ini kepala sekolah atau pengawas pendidikan merinci jenis supervisi apa yang akan dilakukan, waktu pelaksanaan, metode yang digunakan, penilaian guru berdasarkan hasil supervisi, dan evaluasi kegiatan supervisi.

b. Pelaksanaan supervisi

Tahap pelaksanaan supervisi dilakukan berdasarkan perencanaan yang telah 
lebih dulu dibuat. Supervisi profesionalitas guru di masa pandemi corona dapat dilakukan melalui wawancara via telepon dengan guru yang bersangkutan, peserta didik, dan juga orang tua. Supervisi ini bertujuan untuk dapat mengetahui kinerja seorang guru melaksanakan kegiatan pembelajaran tanpa tatap muka.

c. Penilaian hasil supervisi

Penilaian terhadap hasil supervisi dilakukan oleh pengawas pendidikan untuk dijadikan bahan evaluasi.

d. Evaluasi hasil supervisi

Pada tahap evaluasi hasil supervisi bisa diketahui apakah kinerja guru sudah berjalan dengan baik atau ada kekurangan dalam pelaksanaan pembelajaran jara jauh.

e. Perbaikan

Perbaikan ini mencakup dua hal, pertama perbaikan kualitas kompetensi dan keterampilan guru dalam kegiatan belajar mengajar selama pandemi corona. Kedua adalah perbaikan teknik dan sistematika supervisi profesionalitas guru selama pandemi corona agar supervisi selanjutnya dapat lebih efektif dan efisien.

Supervisi profesionalitas guru harus dilaksanakan di masa pandemi Covid 19. Pohan (2020) dalam penelitiannya tentang supervisi kepala madrasah di masa pandemi menjelaskan bahwa kepala sekolah dapat melakukan supervisi akademik dengan mengimplementasikan hal-hal berikut, yaitu: (1) perencanaan pembelajaran, yaitu dengan memberi pengarahan dalam membuat tujuan pembelajaran, materi pembelajaran, metode dan media pembelajaran; (2) pelaksanaan pembelajaran, yaitu dengan pemberian contoh dalam membuka pembelajaran, menyajikan materi pembelajaran, serta penggunaan metode dan media pembelajaran; (3) evaluasi pembelajaran, dengan mengontrol penyusunan perangkat pembelajaran hingga penilaian belajar siswa.

Supervisi di masa pandemi juga perlu penyesuaian. Warmasyah (2020) dalam penelitiannya menjelaskan bahwa supervisi akademik di masa pandemi harus tetap berlangsung. Kepala sekolah harus terus mendampingi, membimbing dan mengawasi kegiatan pembelajaran agar tetap berjalan dengan baik. Mengingat aturan dan pelaksanaan pembelajaran di masa pandemi berbeda dengan kondisi normal, maka banyak hal yang harus disesuaikan. Untuk membahas berbagai masalah yang ada, supervisi dapat dilakukan setiap hari dengan memanfaatkan media on-line.

Supervisi dan koordinasi di masa pandemi menjadi cukup berbeda. Meskipun demikian, kepala sekolah harus bisa menjalankan fungsinya dengan optimal. Supriadi (2020) menjelaskan bahwa dimasa pandemi peranan kepala sekolah memiliki sedikit perbedaan dengan peranannya di masa sebelum pandemi. Peranan kepala sekolah yang sangat diperlukan di masa pandemi adalah sebagai manajer, administrator, supervisor, inovator dan motivator. Meskipun dengan kondisi yang berbeda, Kepala sekolah harus bisa menjalankan peranannya dengan maksimal untuk menjaga kualitas pendidikan di lembaga yang dipimpinnya. 


\section{KESIMPULAN}

Berdasarkan pada pembahasan mengenai supervisi profesionalitas guru di masa pandemi corona, dapat disimpulkan bahwa; pertama, supervisi pendidikan mutlak diperlukan untuk mengetahui kualitas pembelajaran beserta segala bentuk administrasinya. Kedua, supervisi profesionalitas guru di masa pademi corona juga penting dan bahkan wajib dilakukan. Hal itu bertujuan agar dapat mengetahui tingkat kinerja guru dalam melakukan serangkaian pembelajaran jarak jauh. Sebagai seorang guru sudah seharusnya untuk menjalankan tugas dan kewajibannya dalam kondisi apapun, termasuk kondisi yang mengharuskan melakukan pembelajaran jarak jauh. Ketiga, supervisi profesionalitas guru di masa pandemi corona ini dapat dilakukan dalam beberapa tahap, yakni : tahap perencanaan, tahap pelaksanaan, tahap penilaian, tahap evaluasi, dan tahap perbaikan. Kelima tahapan itu dilakukan untuk dapat mengadakan supervisi profesionalitas guru dan mendapat supervisi yang maksimal.

\section{REFERENSI}

Arikunto, S. (2004). Dasar-Dasar Supervisi. Jakarta: Rineka Cipta.

Djamarah, dan Aswan Zain. (2002). Strategi Belajar Mengajar. Jakarta: Rineka Cipta.

Maralih. (2014). Peranan Supervisi dalam Peningkatan Kualitas Pendidikan. Jurnal Qathrunâ, Vol. 1 No.1.

Mukhtar \& Iskandar. (2009). Orientasi Baru Supervisi Pendidikan. Jakarta: Gaung Persada.

Nawawi, Hadary. (1996). Administrasi Pendidikan. Jakarta: Gunung Agung.

Pidarta, Made. (1992). Manajemen Pendidikan Indonesia. Jakarta: Bina Aksara.

Prasojo, Lantip Diat \& Sudiyono. (2011). Supervisi Pendidikan. Yogyakarta: Gava Media.

Pohan, M. M. (2020). Implementasi Supervisi Akademik Kepala Madrasah di Masa Pandemi Covid 19. Idarah (Jurnal Pendidikan dan Kependidikan), 4(2), 195-208.

Purwanto, M Ngalim. (2007). Administrasi dan Supervisi Pendidikan. Bandung: PT Remaja Rosda Karya.

Rifa'i, M. (1987). Administrasi dan Supervisi Pendidikan. Bandung: Jemmars.

Saefudin, Udin. (2009). Proses Pembelajaran. Bandung: Alfa Beta.

Sagala, S. (2010). Supervisi Pembelajaran dalam Profesi Pendidikan. Bandung: Alfabeta.

Sanusi, Ahmad. (1991). Studi Pengembangan Model Pendidikan Profesional Tenaga Kependidikan. Bandung: IKIP

Sulisworo, D. (2013). The Paradox on IT literacy and science's learning achievement in secondary school. International Journal of Evaluation and Research in Education (IJERE), 2(4).

Suhardan, D. (2010). Supervisi Profesional (Layanan dalam Meningkatkan Mutu Pengajaran di Era Otonomi Daerah). Bandung: Alfabeta.

Sukatin. (2016). Manajemen Supervisi Dalam Pendidikan (Studi Kasus di MAN Model Jambi). HIKMAH: Jurnal Pendidikan Islam, Vol. 5, No. 2.

Supriadi, O. (2020). Peranan Kepala PAUD dalam Penyelenggaraan Pendidikan Sebelum dan Saat Terjadi Pandemi Covid-19. Jurnal Obsesi: Jurnal Pendidikan Anak Usia Dini, 5(1), 841-856.

Warmansyah, J. (2020). Supervisi Akademik Kepala Sekolah Taman Kanak-kanak Dimasa Pandemi Covid 19. Tadbir: Jurnal Studi Manajemen Pendidikan, 4(2), 175188. 